Check for updates

Cite this: RSC Adv., 2020, 10, 18853

Received 21st February 2020

Accepted 8th May 2020

DOI: 10.1039/d0ra01651a

rsc.li/rsc-advances

\title{
The linkers in fluorene-labeled 2 '-deoxyuridines affect fluorescence discriminating phenomena upon duplex formation $\uparrow$
}

\begin{abstract}
So Young Lee, ${ }^{a}$ Seung Woo Hong, ${ }^{a}$ Hyeonuk Yeo (D) *b and Gil Tae Hwang (D) *a
Three fluorene-labeled $2^{\prime}$-deoxyuridines that differ in terms of their linkers $-\mathrm{U}^{\mathrm{F}}$ (without linker), $\mathrm{U}^{\mathrm{FL}}$ (with ethynyl linker), and $U^{D F}$ (with diethynyl linker)-have been introduced at the central positions of oligodeoxynucleotides to examine the effects that their linkers have on the fluorescence emission properties upon duplex formation with fully matched and single-base-mismatched targets. Here, we describe the influence of the linkers on the emission behavior, the intramolecular electron transfer between the fluorene moiety and the uracil base after photoexcitation, and the structural stability upon duplex formation. The probe containing the $\mathrm{U}^{\mathrm{FL}}$ residue (with an ethynyl linker) and cytosine residues as flanking bases exhibited the greatest fluorescence turn-on selective behavior toward the perfectly matched target.
\end{abstract}

\section{Introduction}

Detection of single nucleotide polymorphisms (SNPs) is an important aspect of the identification and diagnosis of diseasecausing genes. ${ }^{1}$ Molecular beacons (MBs) featuring fluorophore and quencher units at the ends of their stems are used widely for the detection and analysis of SNPs. ${ }^{2}$ In the absence of a specific target, the emission of an MB is quenched as a result of the proximity of the fluorophore and quencher units; in contrast, duplex formation with the target nucleic acid results in a large increase in the fluorescence intensity. Interestingly, sequence-specific detection of nucleic acids is also possible when using fluorescently labeled oligonucleotide probes that feature no quencher unit. ${ }^{3}$ Recently, we developed a quencherfree MB system in which a $2^{\prime}$-deoxyuridine residue was linked to fluorene derivatives as labels through an ethynyl linker., That system could distinguish, through changes in fluorescence intensity, perfectly matched from single-base-mismatched sequences. Based on differences in the reducibility of nucleobases, intramolecular charge transfer (ICT) from fluorene derivatives to flanking pyrimidine residues ( $\mathrm{C}$ or $\mathrm{T}$ ) upon photoexcitation results in efficient quenching of singlestranded oligodeoxynucleotides (ssODNs) and single-base mismatched double-stranded ODNs (Fig. 1a). ${ }^{6}$ In addition, ODNs featuring C-flanking bases (C-FBs) can display additionally

${ }^{a}$ Department of Chemistry and Green-Nano Materials Research Center, Kyungpook National University, Daegu 41566, Republic of Korea. E-mail: giltae@knu.ac.kr ${ }^{b}$ Department of Chemistry Education, Kyungpook National University, Daegu 41566, Republic of Korea. E-mail: yeo@knu.ac.kr

$\dagger$ Electronic supplementary information (ESI) available. See DOI: 10.1039/d0ra01651a decreased fluorescence when hybridized with all-mismatched targets, when compared with that of ssODNs. This dramatic quenching arises because pairs of guanine bases (i.e., the complementary bases of C-FBs) act as internal quenchers when approached by the fluorene derivative. ${ }^{7}$ When the ODN encounters a perfectly matched target, however, this quenching is inhibited and the emission of the fluorene derivative is restored. Because an acetylene unit linking the fluorene derivatives to the $2^{\prime}$-deoxyuridine residue is efficient at mediating these electron transfer processes, fluorophore-labeled deoxyuridines featuring ethynyl linkers have been studied widely as fluorescent probes. ${ }^{8}$

The ICT process is dependent on two features: (i) the energy difference between the donor's highest occupied molecular orbital (HOMO) and the acceptor's lowest unoccupied

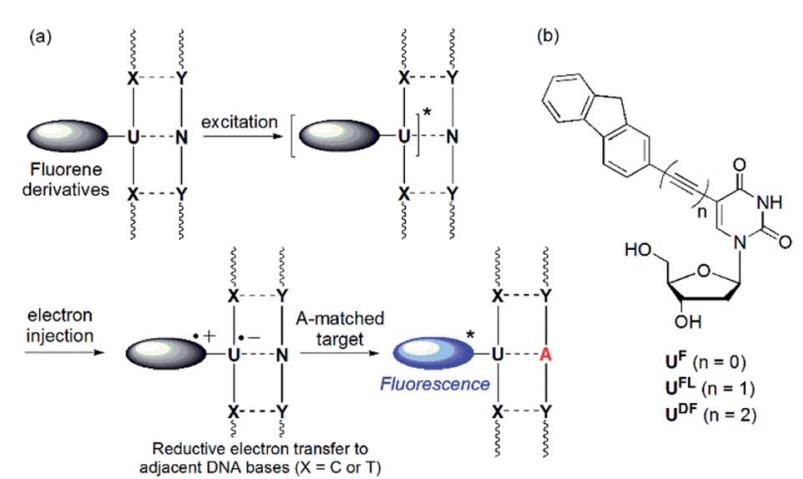

Fig. 1 (a) Mechanism of operation of quencher-free MB systems. (b) Structures of fluorene-labeled 2'-deoxyuridines featuring various linkers. 
molecular orbital (LUMO) and (ii) the nature of the spacer mediating electron transfer between the two groups. In this study, we investigated how SNP probes would operate in the absence of a linker, and when a diethynyl unit was used as an alternative to an ethynyl moiety, linking the fluorene and $2^{\prime}$ deoxyuridine moieties (Fig. 1b). In previous studies, $2^{\prime}$-deoxyuridine residues labeled with chromophores through by a single $\mathrm{C}-\mathrm{C}$ bond (i.e., linker-free systems) have been developed as fluorescence turn-on probes for the detection of an abasic site, ${ }^{9}$ triple-helix formation, ${ }^{\mathbf{1 0}}$ a matched adenosine target ${ }^{\mathbf{1 1}}$ and isomorphic thymine analogues. ${ }^{12}$ The only previously reported example of a DNA probe featuring a $2^{\prime}$-deoxyuridine residue labeled with a diethynyl linker was described by the Brown group, ${ }^{13}$ but their anthracene-labeled $2^{\prime}$-deoxyuridine residue featuring a diacetylenic unit could not discriminate effectively between matched and one-base-mismatched targets through changes in fluorescence intensity.

\section{Results and discussion}

$\mathbf{U}^{\mathbf{F}}$ and $\mathbf{U}^{\mathbf{D F}}$ were synthesized from $2^{\prime}$-deoxy-5-iodouridine (1) through a Suzuki reaction (Scheme 1a) with fluorene-2-boronic acid pinacol ester (2) and a Sonogashira reaction (Scheme 1b) with 2-(buta-1,3-diynyl)fluorene (6), respectively. $\mathbf{U}^{\mathbf{F L}}$ was synthesized using previously reported procedures. ${ }^{4 f}$ To obtain 2 (buta-1,3-diynyl)fluorene (6), we performed Cadiot-Chodkiewicz coupling ${ }^{\mathbf{1 4}}$ of (bromoethynyl)triisopropylsilane $(3)^{15}$ and 2ethynylfluorene (4), ${ }^{16}$ followed by deprotection of the triisopropylsilyl group using tetrabutylammonium fluoride. After protecting the $\mathrm{OH}$ groups of $\mathbf{U}^{\mathbf{F}}$ and $\mathbf{U}^{\mathbf{D F}}$ with DMTr units, we

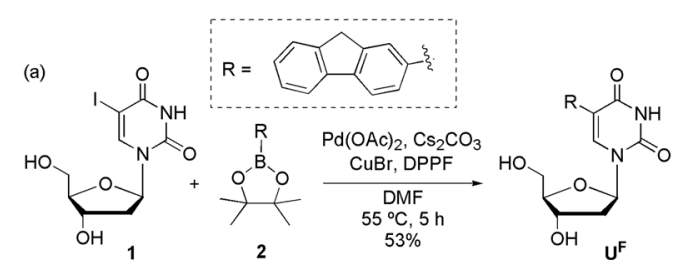

(b)

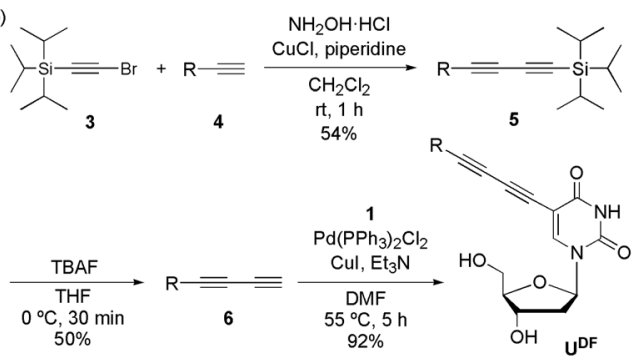

(c)

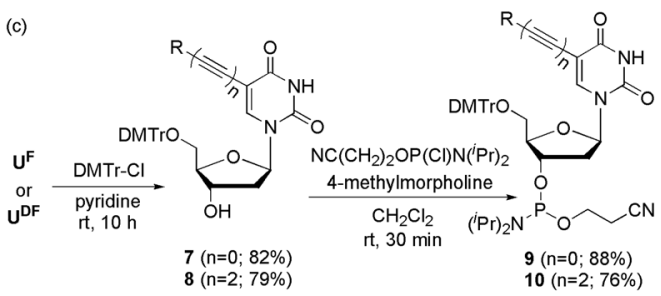

Table 1 Photophysical data for $\mathrm{U}^{\mathrm{F}}, \mathrm{U}^{\mathrm{FL}}$ and $\mathrm{U}^{\mathrm{DF}}$ in $\mathrm{MeOH}$ at $25^{\circ} \mathrm{C}$

\begin{tabular}{lllll}
\hline Nucleoside & $\lambda_{\max } / \mathrm{nm}^{a}$ & $\varepsilon / \mathbf{M}^{-1} \mathrm{~cm}^{-1}$ & $\lambda_{\mathrm{em}} / \mathrm{nm}^{b}$ & $\Phi_{\mathrm{F}}{ }^{c}$ \\
\hline $\mathbf{U}^{\mathbf{F}}$ & 310 & 89000 & 419 & 0.16 \\
$\mathbf{U}^{\mathbf{F L} d}$ & 369 & 25000 & 453 & 0.26 \\
$\mathbf{U}^{\mathbf{D F}}$ & 363 & 26000 & 418 & 0.022
\end{tabular}

${ }^{a}$ Only the largest absorption maxima are listed. ${ }^{b}$ Wavelength of emission maximum when excited at the absorption maximum. ${ }^{c}$ Quantum efficiencies determined using a cyclohexane solution of pyrene $\left(\lambda_{\text {ex }}=313 \mathrm{~nm}\right)$ for $\mathbf{U}^{\mathbf{F}}$, a solution of quinine sulfate in $0.1 \mathrm{~N}$ $\mathrm{H}_{2} \mathrm{SO}_{4}\left(\lambda_{\text {ex }}=350 \mathrm{~nm}\right)$ for $\mathbf{U}^{\mathbf{F L}}$ and a solution of fluorescein in $0.1 \mathrm{~N}$ $\mathrm{NaOH}\left(\lambda_{\mathrm{ex}}=366 \mathrm{~nm}\right)$ for $\mathbf{U}^{\mathrm{DF}}$ as standards. ${ }^{18}$ Data are presented as mean values from three independent experiments. ${ }^{d}$ Taken from ref. 17.

converted the nucleosides to the phosphoramidites $\mathbf{9}$ and $\mathbf{1 0}$, respectively (Scheme 1c).

Initially, we measured the absorption and emission spectra of the free nucleosides in $\mathrm{MeOH}$ (Table 1 and Fig. $\mathrm{S} 1 \dagger$ ). $\mathbf{U}^{\mathbf{F}}$ exhibited the highest absorbance among our three tested nucleosides; $\mathbf{U}^{\mathbf{F L}}$ displayed red-shifted absorption and emission signals relative to those of the more highly conjugated $\mathbf{U}^{\mathbf{D F}}$. To determine the causes of these phenomena, we employed time-dependent density functional theory (TDDFT) to calculate the optimized structures of the ground and excited states of these nucleosides in vacuo (Fig. S2 and S3†). The dihedral angles between the fluorene and uracil moieties in the optimized structures of the ground states were $23.29^{\circ}$ for $\mathbf{U}^{\mathbf{F}}, 0.77^{\circ}$ for $\mathbf{U}^{\mathbf{F L}}$ and $10.21^{\circ}$ for $\mathbf{U}^{\mathbf{D F}}$; in their excited states they were $4.94,3.95$ and $26.87^{\circ}$, respectively. For both $\mathbf{U}^{\mathbf{F}}$ and $\mathbf{U}^{\mathbf{D F}}$, the absorption maximum was blueshifted relative to that of $\mathbf{U}^{\mathbf{F L}}$ because the dihedral angles between their fluorene and uracil moieties were twisted in the ground state (i.e., less effective conjugation). In addition, the emission maximum of $\mathbf{U}^{\mathbf{D F}}$ was similar to that of $\mathbf{U}^{\mathbf{F}}$ (which featured a planar dihedral angle in the excited state) and much more blue-shifted than that of $\mathbf{U}^{\mathbf{F L}}$, because $\mathbf{U}^{\mathbf{D F}}$ remained relatively twisted in its excited state. This twist was presumably responsible for the low fluorescence yield of the $\mathbf{U}^{\mathbf{D F}}$.

We used a DNA synthesizer and the phosphoramidites $\mathbf{9}$ and $\mathbf{1 0}$ to incorporate the $\mathbf{U}^{\mathbf{F}}$ and $\mathbf{U}^{\mathbf{D F}}$ residues, respectively, at the central positions of ODNs (Table 2). We characterized these ODNs using matrix-assisted laser desorption ionization time-of-flight (MALDITOF) mass spectrometry (Table $\mathrm{S} 1 \dagger$ ). To determine the suitability of these ODNs as SNP probes, we positioned pyrimidine bases $(\mathrm{C}$ or $\mathrm{T}$ ) as FBs for the $\mathbf{U}^{\mathbf{F}}$ and $\mathbf{U}^{\mathbf{D F}}$ residues and compared their effects with those previously reported for $\mathbf{U}^{\mathrm{FL}}$ residues.

Table 2 ODNs tested in this study

\begin{tabular}{ll}
\hline ODN $^{a}$ & Sequence \\
\hline ODN1(X) & $5^{\prime}$-d(TGG ACT TXT TCA ATG)-3' \\
ODN1'(N) & $3^{\prime}$-d(ACC TGA ANA AGT TAC)-5' \\
ODN2(X) & $5^{\prime}$-d(TGG ACT CXC TCA ATG)-3' \\
ODN2 $^{\prime}(\mathrm{N})$ & $3^{\prime}$-d(ACC TGA GNG AGT TAC)-5'
\end{tabular}

${ }^{a} \mathbf{X}: \mathbf{U}^{\mathrm{F}}, \mathbf{U}^{\mathrm{FL}}$ or $\mathbf{U}^{\mathrm{DF}} ; \mathrm{N}: \mathrm{A}, \mathrm{T}, \mathrm{G}$ or $\mathrm{C}$.
Scheme 1 Synthesis of (a) $U^{F}$, (b) $U^{D F}$ and (c) their phosphoramidites 9 and 10 , respectively. 
Table 3 Total discrimination factors of ODN1 bearing T-FBs and ODN2 bearing $\mathrm{C}-\mathrm{FBs}^{a}$

\begin{tabular}{lcll}
\hline Duplex $^{b}$ & $\mathbf{U}^{\mathbf{F}}$ & $\mathbf{U}^{\mathbf{F L} c}$ & $\mathbf{U}^{\mathbf{D F}}$ \\
\hline ODN1(X)/ODN1'(A) & 37 & 4.6 & 0.91 \\
ODN1(X)/ODN1'(T) & 23 & 2.1 & 0.54 \\
ODN1(X)/ODN1'(G) & 19 & 0.96 & 0.43 \\
ODN1(X)/ODN1'(C) & 23 & 2.5 & 0.63 \\
ODN2(X)/ODN2'(A) & 5.7 & 4.0 & 2.6 \\
ODN2(X)/ODN2'(T) & 1.6 & 0.39 & 0.72 \\
ODN2(X)/ODN2'(G) & 1.1 & 0.35 & 0.67 \\
ODN2(X)/ODN2'(C) & 2.9 & 0.27 & 0.91
\end{tabular}

${ }^{a}$ Area ratio of fluorescence intensity relative to those of corresponding ssODNs. ${ }^{b} \mathbf{X}: \mathbf{U}^{\mathrm{F}}, \mathbf{U}^{\mathrm{FL}}$ or $\mathbf{U}^{\mathrm{DF}} .{ }^{c}$ Taken from ref. $4 a$.

First, we investigated the discrimination against singlenucleotide variants exhibited by the fluorescent ODN1 featuring T-FBs (Fig. 2). When the ODN1s containing $\mathbf{U}^{\mathbf{F}}$ and $\mathbf{U}^{\mathbf{F L}}$ residues formed their matched duplexes, their emissions were enhanced 37 and 4.6 times, respectively, relative to those of the ssODN1s (Table 3). Notably, the fluorescence of ODN1( $\left.\mathbf{U}^{\mathbf{F}}\right)$ itself was almost completely quenched through effective ICT; it recovered completely upon formation of its matched duplex. ODN1 $\left(\mathbf{U}^{\mathbf{F L}}\right)$, featuring an acetylenic linker, did not experience ICT as effective as that of $\mathbf{U}^{\mathbf{F}}$. Furthermore, when forming mismatched duplexes, the ODN1s containing $\mathbf{U}^{\mathbf{F}}$ and $\mathbf{U}^{\mathbf{F L}}$ residues provided fluorescence increases greater than those of the ssODN1s, in most cases, making it difficult to use them as Aselective SNP probes. All of the matched and mismatched duplexes of ODN1 $\left(\mathbf{U}^{\mathbf{D F}}\right)$ displayed emissions slightly lower than those of ssODN1 $\left(\mathbf{U}^{\mathbf{D F}}\right)$. These results indicate that ODN1 $\left(\mathbf{U}^{\mathbf{D F}}\right)$ featuring T-FBs and diacetylenic linker did not produce effective ICT or its formation of duplex with A-matched target did not inhibit fluorescence quenching caused by the ICT process.

Next, we investigated the fluorescence behavior of the ODN2 featuring C-FBs (Fig. 3). The fluorescence of the matched duplex of ODN2 $\left(\mathbf{U}^{\mathbf{F L}}\right)$ was four-fold greater than that of $\operatorname{ssODN} 2\left(\mathbf{U}^{\mathbf{F L}}\right)$; the mismatched duplexes exhibited decreases in emission that were more than twice that of ssODN, resulting from the quinine-quenching effect (G-effect). Similar to the situation for ODN1 $\left(\mathbf{U}^{\text {DF }}\right)$ having T-FBs, ODN2( $\left.\mathbf{U}^{\text {DF }}\right)$ featuring C-FBs displayed decreased fluorescence relative to that of ssODN when forming duplexes with mismatched targets. However, the formation of duplex with A-matched target showed only a 2.6-fold increase in fluorescence relative to that of $\operatorname{ssODN} 2\left(\mathbf{U}^{\mathbf{D F}}\right)$. In other words, the diacetylenic linker did not facilitate effective ICT. Interestingly, when ODN2 $\left(\mathbf{U}^{\mathbf{F}}\right)$ formed its matched duplex, there was a 5.7-fold increase in fluorescence relative to that of $\operatorname{ssODN} 2\left(\mathbf{U}^{\mathbf{F}}\right)$ - slightly higher than the 4.0 -fold increase of $\operatorname{ssODN} 2\left(\mathbf{U}^{\mathbf{F L}}\right)$. Thus, it appeared that the linker-free $\mathbf{U}^{\mathbf{F}}$ residue was slightly more suitable for effective electronic coupling between the fluorene and uracil moieties for ICT than was the $\mathbf{U}^{\mathbf{F L}}$ residue featuring an acetylenic linker. Nevertheless, ODN2 $\left(\mathbf{U}^{\mathbf{F}}\right)$ exhibited slightly increased emissions upon hybridization with all of its mismatched targets, resulting in $1.6(\mathrm{~T})-, 1.1(\mathrm{G})$ - and $2.9(\mathrm{C})$-fold enhancements in its emission intensities relative to that of $\operatorname{ssODN} 2\left(\mathbf{U}^{\mathbf{F}}\right)$. That is, the G-effect observed for ODN2 $\left(\mathbf{U}^{\mathbf{F L}}\right)$ did not operate for ODN2 $\left(\mathbf{U}^{\mathbf{F}}\right)$. We suspect that the fluorene unit was located too close to the duplexes of ODN2 $\left(\mathbf{U}^{\mathbf{F}}\right)$, such that partial distortion of the duplex structure (or of the dihedral angle between the fluorene and uracil moieties) occurred when forming mismatched duplexes; thus, it was less likely that the G-effect or ICT through photoexcitation could be generated. We measured melting temperatures to compare the thermal stabilities of the duplexes formed using the ODN2s (Table 4). The A-selective thermal stability observed for the duplexes of ODN2 $\left(\mathbf{U}^{\mathbf{F L}}\right)$ was not evident for ODN2 $\left(\mathbf{U}^{\mathbf{F}}\right)$ and ODN2 $\left(\mathbf{U}^{\mathbf{D F}}\right)$. That is, the values of $T_{\mathrm{m}}$ for the mismatched duplexes of ODN2( $\left.\mathbf{U}^{\mathbf{F}}\right)$ and ODN2 $\left(\mathbf{U}^{\mathbf{D F}}\right)$ were higher than those of ODN2 $\left(\mathbf{U}^{\mathbf{F L}}\right)$. This phenomenon was presumably caused by the structural modification of the $\mathbf{U}^{\mathbf{F}}$ and $\mathbf{U}^{\mathbf{D F}}$ residues, and additionally weaker Geffects, making them ineffective DNA probes.

In summary, effective electron transfer between the two moieties occurred when the fluorene and uracil units were connected directly without a linker. This tendency was more pronounced when T-FBs were involved, resulting in a 37-fold increase in fluorescence when forming duplexes with $\mathrm{A}$ matched targets. The application of a $\mathbf{U}^{\mathbf{F}}$ residue, however, was not suitable for discriminating mismatched duplexes. In addition, ODNs featuring a $\mathbf{U}^{\mathbf{D F}}$ residue, bearing a diacetylenic linker, were not useful as SNP probes because of low quantum yields and no electron transfer between the fluorene and uracil moieties, due to their twisted dihedral angle in the excited state.
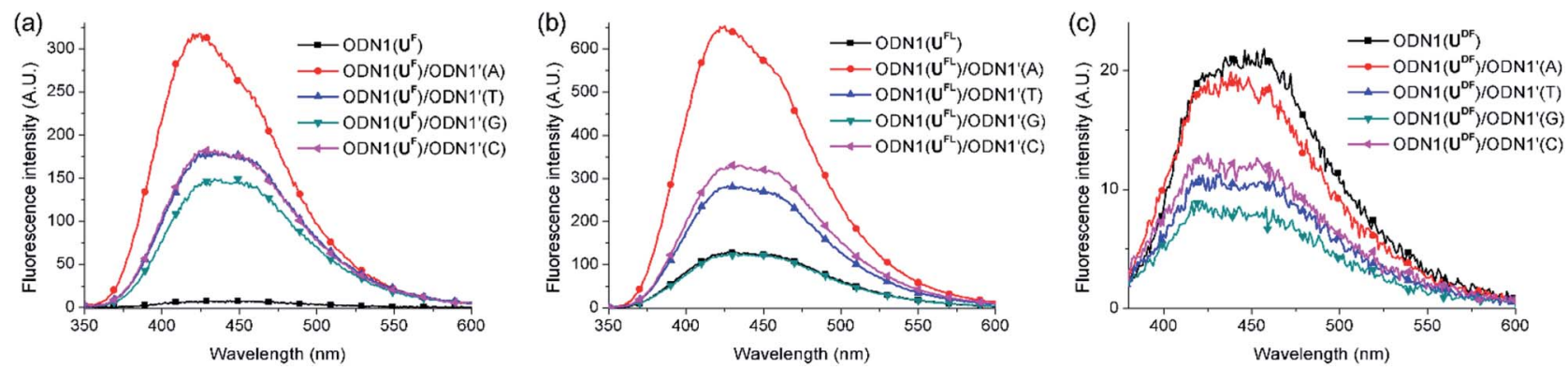

Fig. 2 Fluorescence spectra of probes featuring T-FBs, recorded in $10 \mathrm{mM}$ Tris- $\mathrm{HCl}$ buffer $(\mathrm{pH} 7.2 ; 100 \mathrm{mM} \mathrm{NaCl}, 20 \mathrm{mM} \mathrm{MgCl}$ ): ssODN1s and

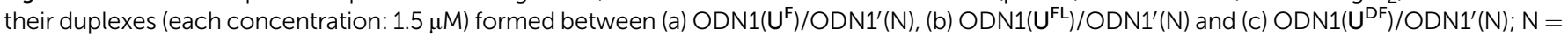
A, T, G or C. Excitation wavelength: absorption maximum. 

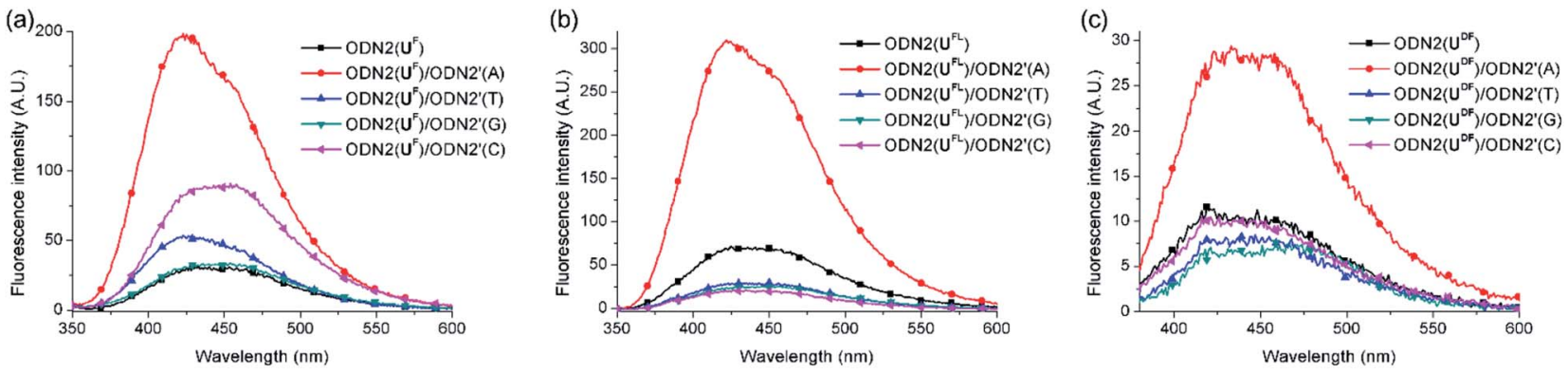

Fig. 3 Fluorescence spectra of probes featuring C-FBs, recorded in $10 \mathrm{mM}$ Tris- $\mathrm{HCl}$ buffer $(\mathrm{pH} 7.2 ; 100 \mathrm{mM} \mathrm{NaCl}, 20 \mathrm{mM} \mathrm{MgCl}$ ): ssODN2s and

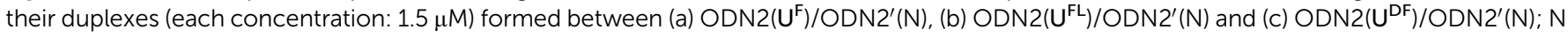
$=\mathrm{A}, \mathrm{T}, \mathrm{G}$ or $\mathrm{C}$. Excitation wavelength: absorption maximum.

Table 4 Melting temperatures $\left(T_{m}\right)$ of duplexes ${ }^{a}$

\begin{tabular}{lllll}
\hline Duplex & $\mathbf{X}=\mathrm{T}$ & $\mathbf{X}=\mathbf{U}^{\mathbf{F}}$ & $\mathbf{X}=\mathbf{U}^{\mathrm{FL}}$ & $\mathbf{X}=\mathbf{U}^{\mathbf{D F}}$ \\
\hline ODN2(X)/ODN2'(A) & 57.3 & 48.3 & 48.7 & 49.5 \\
ODN2(X)/ODN2'(T) & 49.4 & 46.9 & 42.8 & 46.5 \\
ODN2(X)/ODN2'(G) & 51.8 & 45.6 & 43.6 & 47.8 \\
ODN2(X)/ODN2'(C) & 47.1 & 47.8 & 45.8 & 47.9
\end{tabular}

${ }^{a}$ All values of $T_{\mathrm{m}}(1.5 \mu \mathrm{M})$ were measured in $10 \mathrm{mM}$ Tris-HCl buffer $(100 \mathrm{mM} \mathrm{NaCl}, 20 \mathrm{mM} \mathrm{MgCl}$; $\mathrm{pH} 7.2)$ and are provided as averages from three independent measurements.

The $\mathbf{U}^{\mathbf{F L}}$ residue, bearing an ethynyl linker, did, however, feature an appropriate distance between the fluorene and uracil moieties to ensure effective electron transfer and structural stability of its duplexes. Nevertheless, the electron transfer of $\mathbf{U}^{\mathbf{F L}}$ was less effective than that of $\mathbf{U}^{\mathbf{F}}$; furthermore, ODN2 $\left(\mathbf{U}^{\mathbf{F L}}\right)$ featuring C-FBs also displayed an effective G-effect and could, therefore, act as an A-selective SNP probe. ${ }^{19}$

\section{Conclusions}

A previously reported quencher-free MB system featuring a $2^{\prime}$ deoxyuridine residue $\left(\mathbf{U}^{\mathbf{F L}}\right)$ labeled with a fluorene moiety (separated by an ethynyl linker) and C-FBs could discriminate a perfectly matched DNA target through an enhancement in fluorescence intensity. This discrimination originated from (i) effective ICT between the fluorene and uracil moieties after photoexcitation and (ii) the quenching effect of guanine residues that were complementary to the cytosine bases positioned as the FBs of the $\mathbf{U}^{\mathbf{F L}}$ residue. As potential alternatives to the ethynyl linker, in this present study we prepared the linker-free $\mathbf{U}^{\mathbf{F}}$ and the $\mathbf{U}^{\mathbf{D F}}$ featuring a diacetylenic linker, as well as their corresponding DNA probes. The emission of the isolated probe containing the $\mathbf{U}^{\mathbf{F}}$ residue was quenched through prominent ICT, but a large increase in fluorescence occurred when it met its matched target. Nevertheless, the fluorene moiety (in the absence of a linker) affected the three-dimensional structure of the mismatched duplexes, such that an effective G-effect was rare, resulting in low discrimination of mismatched targets. On the other hand, the presence of a diethynyl linker twisted the dihedral angle between the fluorene moiety and the uracil base, inhibiting electron transfer between the two moieties, such that its ODNs did not function as probes at all. Overall, the ethynyl linker was most suitable for positioning between the fluorene and uracil moieties. Because the $\pi$-conjugated bridge in $\mathbf{U}^{\mathbf{F L}}$ was quite planar, an electron could be transferred smoothly from the fluorene donor to the uracil acceptor. On the other hand, none of the probes featuring T-FBs exhibited selective fluorescence increases for their matched targets, due to the lack of a Geffect. Thus, the nature of the linker had a great influence on the dihedral angle and fluorescence properties of the nucleosides, as well as their propensity for electron transfer. Therefore, the selection of a suitable linker is one of the most important factors when designing a probe.

\section{Experimental}

\section{General}

All reactions were performed in dry glassware under Ar atmospheres. Analytical thin layer chromatography (TLC) was performed using Merck $60 \mathrm{~F}_{254}$ silica gel plates; column chromatography was performed using Merck 60 silica gel (230400 mesh). Melting points were determined using an Electrothermal IA 9000 series melting point apparatus and are uncorrected. Optical rotations $[\alpha]_{\mathrm{D}}$ were measured on a Rudolph Research Analytical AUTOPOL I polarimeter. Infrared (IR) spectra were recorded using a JASCO FT/IR-4100 spectrometer. ${ }^{1} \mathrm{H},{ }^{13} \mathrm{C}$ and ${ }^{31} \mathrm{P}$ NMR spectra were recorded using a Bruker NMR spectrometer (AVANCE III $500 \mathrm{MHz}$ ). High-resolution fast atom bombardment (FAB) mass spectra were recorded using a JEOL JMS-700 mass spectrometer, at the Daegu Center of KBSI, Korea. All commercially available chemicals were used without further purification; solvents were carefully dried and distilled prior to use. The synthesis of $\mathbf{U}^{\mathrm{FL}}$ has been reported previously. ${ }^{4 f}$

\section{Synthetic procedures}

2'-Deoxy-5-(9H-fluoren-2-yl)uridine ( $\left.\mathbf{U}^{\mathbf{F}}\right)$. 2'-Deoxy-5-iodouridine (1; $270 \mathrm{mg}, 0.762 \mathrm{mmol}$ ), fluorene-2-boronic acid pinacol ester (2; $668 \mathrm{mg}, 2.29 \mathrm{mmol}$ ), $\mathrm{Cs}_{2} \mathrm{CO}_{3}$ (993 mg, $3.05 \mathrm{mmol}$ ), $\mathrm{Pd}(\mathrm{OAc})_{2}$ (17.1 mg, $0.0726 \mathrm{mmol}$ ), DPPF (84.4 mg, $0.152 \mathrm{mmol}$ ) and $\mathrm{CuBr}$ (190 mg, $0.762 \mathrm{mmol}$ ) were dissolved in distilled DMF $(7.6 \mathrm{~mL})$. Argon was bubbled through the solution and then a pump/purge process was performed with the injection of Ar gas. The mixture 
was stirred at $55{ }^{\circ} \mathrm{C}$ for $5 \mathrm{~h}$. After evaporation of the solvent in vacuo, the residue was purified through column chromatography ( $\mathrm{SiO}_{2}$; hexane/EtOAc, $\left.1: 1\right)$ to yield $\mathbf{U}^{\mathbf{F}}(159 \mathrm{mg}, 53 \%): \mathrm{mp}>150{ }^{\circ} \mathrm{C}$ dec; $[\alpha]_{\mathrm{D}}^{13}=-10.0^{\circ}(c=1.00$ in $\mathrm{MeOH})$; IR (film): $\nu$ 3364, 3039, 2933, 1659, 1607, 1591, 1461, 1422, 1351, 1275, 1231, 1089, 1017, 833, $734 \mathrm{~cm}^{-1}$; ${ }^{1} \mathrm{H}$ NMR (500 MHz, $\mathrm{CD}_{3} \mathrm{OD}$ ): $\delta 8.23$ (s, 1H; H-6), $7.70(\mathrm{~d}, J=7.9 \mathrm{~Hz}, 1 \mathrm{H}$; fluorene-H), 7.65 (s, 1H; fluorene-H), 7.47-7.42 (m, 2H; fluorene-H), $7.25(\mathrm{t}, J=7.4 \mathrm{~Hz}, 1 \mathrm{H}$; fluorene$\mathrm{H}), 7.19(\mathrm{td}, J=7.4,0.96 \mathrm{~Hz}, 2 \mathrm{H}$; fluorene- $\mathrm{H}), 6.27(\mathrm{t}, J=6.6 \mathrm{~Hz}$, $1 \mathrm{H} ; \mathrm{H}^{\prime} \mathbf{1}^{\prime}$ ), 4.37 (q, $\left.J=3.6 \mathrm{~Hz}, 1 \mathrm{H} ; \mathrm{H}-3^{\prime}\right), 3.80$ (q, $J=3.1 \mathrm{~Hz}, 1 \mathrm{H} ; \mathrm{H}-$ $4^{\prime}$ ), 3.81 (s, 2H; fluorene- $\mathrm{CH}_{2}$ ), 3.75-3.64 (m, 2H; H-5'), 2.27-2.23 (m, 2H; H-2'); ${ }^{13} \mathrm{C}$ NMR (125 MHz, $\left.\mathrm{CD}_{3} \mathrm{OD}\right): \delta$ 167.0, 164.9, 152.0, 145.0, 144.7, 142.7, 142.6, 139.7, 132.9, 128.3, 128.1, 127.9, 126.2, 121.0, 120.7, 116.6, 89.2, 87.0, 72.2, 62.7, 41.8, 37.8; HRMS-FAB $(\mathrm{m} /$ $z):[\mathrm{M}+\mathrm{H}]^{+}$calcd for $\mathrm{C}_{22} \mathrm{H}_{21} \mathrm{~N}_{2} \mathrm{O}_{5}, 393.1450$; found, 393.1447 .

[4-(9H-Fluoren-2-yl)-buta-1,3-diynyl]triisopropylsilane (5). 2Ethynyl-9H-fluorene $(4 ; 447 \mathrm{mg}, 2.35 \mathrm{mmol}), \mathrm{H}_{2} \mathrm{NOH} \cdot \mathrm{HCl}$ (49.0 mg, $0.705 \mathrm{mmol}$ ) and $\mathrm{CuCl}(35.0 \mathrm{mg}, 0.354 \mathrm{mmol})$ were dissolved in distilled $\mathrm{CH}_{2} \mathrm{Cl}_{2}(4.0 \mathrm{~mL})$ and piperidine $(580 \mu \mathrm{L}$, $5.87 \mathrm{mmol}$ ) was added. A solution of (bromoethynyl)triisopropylsilane $(3 ; 1.22 \mathrm{~g}, 4.67 \mathrm{mmol})$ in $\mathrm{CH}_{2} \mathrm{Cl}_{2}(3.8 \mathrm{~mL})$ was added and then the mixture was stirred at room temperature for $1 \mathrm{~h}$. After evaporation of the solvent in vacuo, the residue was purified through column chromatography $\left(\mathrm{SiO}_{2}\right.$; hexane) to yield $\mathbf{5}$ (470 mg, 54\%): $\mathrm{mp}>83{ }^{\circ} \mathrm{C} \mathrm{dec}$; IR (film): $\nu$ 3058, 2941, 2890, 2865, 2724, 2361, 2202, 2128, 2097, 2066, 1944, 1800, 1669, 1607, 1455, 1382, 1300, 1227, 1148, 1066, 996, 915, 879, 803, 766, 749, 733, 730, 658, 607, $463 \mathrm{~cm}^{-1}$; ${ }^{1} \mathrm{H}$ NMR $(500 \mathrm{MHz}$, $\left.\mathrm{CDCl}_{3}\right): \delta 7.70(\mathrm{~d}, J=7.5 \mathrm{~Hz}, 1 \mathrm{H}$; fluorene-H), $7.65(\mathrm{~d}, J=7.9 \mathrm{~Hz}$, 1H; fluorene-H), 7.61 (s, 1H; fluorene-H), $7.47(\mathrm{~d}, J=3.7 \mathrm{~Hz}, 1 \mathrm{H}$; fluorene-H), $7.46(\mathrm{~d}, J=4.2 \mathrm{~Hz}, 1 \mathrm{H}$; fluorene- $\mathrm{H}), 7.31(\mathrm{t}, J=$ $6.9 \mathrm{~Hz}, 1 \mathrm{H}$; fluorene-H), 7.25 (t, $J=7.4 \mathrm{~Hz}, 1 \mathrm{H}$; fluorene- $\mathrm{H}), 3.81$ (s, 2H; fluorene- $\left.\mathrm{CH}_{2}\right), 1.18(\mathrm{~s}, 3 \mathrm{H} ; \mathrm{CH}), 1.05\left(\mathrm{~s}, 18 \mathrm{H} ; \mathrm{CH}_{3}\right) ;{ }^{13} \mathrm{C}$ NMR (125 MHz, $\mathrm{CDCl}_{3}$ ): $\delta$ 143.7, 143.1, 142.9, 140.8, 131.7, 129.2, 127.5, 126.9, 125.1, 120.4, 119.8, 119.4, 89.7, 87.9, 76.5, 74.7, 36.7, 18.6, 11.3; HRMS-FAB $(\mathrm{m} / \mathrm{z}):[\mathrm{M}]^{+}$calcd for $\mathrm{C}_{26} \mathrm{H}_{30} \mathrm{Si}$, 370.2117 ; found, 370.2119 .

2-Buta-1,3-diynyl-9H-fluorene (6). Tetrabutylammonium fluoride $(1.5 \mathrm{~mL})$ was added to a solution of $5(382 \mathrm{mg}, 1.03 \mathrm{mmol})$ in distilled THF $(3.4 \mathrm{~mL})$ and then the mixture was stirred at $0{ }^{\circ} \mathrm{C}$ for $30 \mathrm{~min}$. After evaporation of the solvent in vacuo, the residue was purified through column chromatography $\left(\mathrm{SiO}_{2}\right.$; hexane) to yield $6(110 \mathrm{mg}, 50 \%)$. CAUTION: this compound was unstable and turned into a black insoluble material upon standing: $\mathrm{mp}>98^{\circ} \mathrm{C}$ dec; IR (film): $\nu$ 3343, 3251, 3056, 2918, 2769, 2206, 2055, 1896, 1666, 1610, 1465, 1452, 1417, 1392, 1299, 1235, 1198, 1146, 1098, 999, 956, 943, 877, 832, 768, 643, 620, $557 \mathrm{~cm}^{-1} ;{ }^{1} \mathrm{H}$ NMR $(500$ $\left.\mathrm{MHz}, \mathrm{CDCl}_{3}\right): \delta 7.80(\mathrm{~d}, J=7.5 \mathrm{~Hz}, 1 \mathrm{H}$; fluorene-H), $7.75(\mathrm{~d}, J=$ $7.9 \mathrm{~Hz}, 1 \mathrm{H}$; fluorene-H), $7.70(\mathrm{~s}, 1 \mathrm{H}$; fluorene- $\mathrm{H}), 7.56(\mathrm{td}, J=6.3$, $0.55 \mathrm{~Hz}, 2 \mathrm{H}$; fluorene-H), $7.40(\mathrm{t}, J=6.9 \mathrm{~Hz}, 1 \mathrm{H}$; fluorene-H), 7.25 (td, $J=7.4,1.2 \mathrm{~Hz}, 1 \mathrm{H}$; fluorene-H), $3.90\left(\mathrm{~s}, 2 \mathrm{H}\right.$; fluorene- $\left.\mathrm{CH}_{2}\right)$, 2.52 (s, $1 \mathrm{H} ; \mathrm{CH}) ;{ }^{13} \mathrm{C}$ NMR (125 $\left.\mathrm{MHz}, \mathrm{CDCl}_{3}\right): \delta$ 143.7, 143.2, 140.7, 131.8, 129.3, 127.6, 127.4, 125.2, 120.5, 119.9, 118.8, 76.3, 73.5, 71.3, 68.4, 36.7; HRMS-FAB $(\mathrm{m} / \mathrm{z}):[\mathrm{M}]^{+}$calcd for $\mathrm{C}_{17} \mathrm{H}_{10}$, 214.0782; found, 214.0785.

2'-Deoxy-5-[(9H-fluoren-2-yl)buta-1,3-diyn-1-yl] uridine $\left(\mathrm{U}^{\mathrm{DF}}\right)$. A solution of 7 (92.0 mg, $0.429 \mathrm{mmol}), 2^{\prime}$-deoxy-5-iodouridine (1;
$76.0 \mathrm{mg}, 0.215 \mathrm{mmol}), \mathrm{Pd}\left(\mathrm{PPh}_{3}\right)_{2} \mathrm{Cl}_{2}(15.0 \mathrm{mg}, 0.0214 \mathrm{mmol})$, CuI (4.00 mg, $0.210 \mathrm{mmol})$ in distilled DMF $(1.6 \mathrm{~mL})$ and trimethylamine $(0.5 \mathrm{~mL})$ was subjected to 10 cycles of a pump/ purge process with the injection of Ar gas. The mixture was then stirred at $55{ }^{\circ} \mathrm{C}$ for $5 \mathrm{~h}$. After evaporation of the solvent in vacuo, the residue was purified through column chromatography $\left(\mathrm{SiO}_{2} ; \mathrm{CH}_{2} \mathrm{Cl}_{2} / \mathrm{MeOH}, 30: 1\right)$ to yield $\mathbf{U}^{\mathbf{D F}}(87 \mathrm{mg}, 92 \%)$ : $\mathrm{mp}>220^{\circ} \mathrm{C} \mathrm{dec} ;[\alpha]_{\mathrm{D}}^{13}=-37.7^{\circ}(c=1.00$ in MeOH$)$; IR (film): $\nu$ 3404, 3187, 3122, 2951, 2813, 2144, 1721, 1660, 1612, 1465, 1316, 1271, 1099, 1049, $829 \mathrm{~cm}^{-1}$; ${ }^{1} \mathrm{H}$ NMR (500 MHz, DMSO$\left.d_{6}\right): \delta 11.77(\mathrm{~s}, 1 \mathrm{H} ; \mathrm{NH}), 8.50(\mathrm{~s}, 1 \mathrm{H} ; \mathrm{H}-6), 7.96(\mathrm{~d}, J=7.8 \mathrm{~Hz}, 2 \mathrm{H}$; fluorene-H), 7.79 (s, $1 \mathrm{H}$; fluorene-H), $7.63(\mathrm{dd}, J=7.2,2.5 \mathrm{~Hz}$, $2 \mathrm{H}$; fluorene-H), $7.42(\mathrm{t}, J=7.3 \mathrm{~Hz}, 1 \mathrm{H}$; fluorene-H), $7.37(\mathrm{td}, J=$ $7.4 \mathrm{~Hz}, 1.1 \mathrm{~Hz}, 1 \mathrm{H}$; fluorene-H), 6.10 (t, $\left.J=6.4 \mathrm{~Hz}, 1 \mathrm{H} ; \mathrm{H}-1^{\prime}\right), 5.27$ $\left(\mathrm{d}, J=4.3 \mathrm{~Hz}, 1 \mathrm{H} ; \mathrm{OH}^{\prime} 3^{\prime}\right), 5.19$ (t, $\left.J=4.9 \mathrm{~Hz}, 1 \mathrm{H} ; \mathrm{OH}^{\prime} 5^{\prime}\right), 4.29-$ 4.25 (m, 1H; H-3'), 3.96 (s, 2H; fluorene- $\left.\mathrm{CH}_{2}\right), 3.82(\mathrm{q}, J=3.3 \mathrm{~Hz}$, $\left.1 \mathrm{H} ; \mathrm{H}-4^{\prime}\right), 3.68-3.57$ (m, 2H; H-5'), 2.18-2.16 (m, $\left.2 \mathrm{H} ; \mathrm{H}-2^{\prime}\right) ;{ }^{13} \mathrm{C}$ NMR (125 MHz, DMSO- $d_{6}$ ): $\delta$ 161.6, 149.2, 146.2, 143.7, 143.4, $142.7,140.1$, 131.4, 128.9, 127.7, 127.0, 125.3, 120.8, 120.5, 118.3, 96.7, 87.7, 85.2, 82.6, 76.6, 75.7, 78.8, 69.8, 60.7, 40.3, 36.3; HRMS-FAB $(\mathrm{m} / \mathrm{z})$ : $[\mathrm{M}]^{+}$calcd for $\mathrm{C}_{26} \mathrm{H}_{20} \mathrm{~N}_{2} \mathrm{O}_{5}, 440.1372$; found, 440.1373 .

$5^{\prime}$-O-(4,4'-Dimethoxytrityl)-2'-deoxy-5-(9H-fluoren-2-yl)uridine (7). 4,4'-Dimethoxytrityl chloride $(220 \mathrm{mg}, 0.649 \mathrm{mmol})$ was added to a solution of $\mathbf{U}^{\mathbf{F}}(200 \mathrm{mg}, 0.510 \mathrm{mmol})$ in anhydrous pyridine $(200 \mu \mathrm{L})$ and then the mixture was stirred under Ar for $10 \mathrm{~h}$ at room temperature. The solvent was evaporated and the residue purified chromatographically $\left(\mathrm{SiO}_{2}\right.$, hexane/EtOAc, $\left.1: 1\right)$ to yield 7 (290 mg, 82\%): $\mathrm{mp}>137^{\circ} \mathrm{C} \mathrm{dec} ;[\alpha]_{\mathrm{D}}^{13}=-6.7^{\circ}(c=1.40$ in $\mathrm{CHCl}_{3}$ ); IR (film): $\nu$ 3476, 3056, 2926, 1691, 1607, 1508, 1461, 1421, 1274, 1249, 1091, 1032, 862, $736 \mathrm{~cm}^{-1}$; ${ }^{1} \mathrm{H}$ NMR $(500 \mathrm{MHz}$, $\left.\mathrm{CDCl}_{3}\right): \delta 8.45(\mathrm{~s}, 1 \mathrm{H} ; \mathrm{NH}), 7.87(\mathrm{~s}, 1 \mathrm{H} ; \mathrm{H}-6), 7.71(\mathrm{~d}, J=7.5 \mathrm{~Hz}$, $1 \mathrm{H}$; fluorene-H), 7.52 (d, $J=7.9 \mathrm{~Hz}, 1 \mathrm{H}$; fluorene-H), 7.45-7.30 (m, 7H; fluorene-H + DMTr-H), 7.22-7.12 (m, 7H; fluorene-H + DMTr-H), 6.64 (dt, $J=8.7,1.9 \mathrm{~Hz}, 4 \mathrm{H}$; DMTr-H), $6.44(\mathrm{t}, J=$ $\left.6.0 \mathrm{~Hz}, 1 \mathrm{H} ; \mathrm{H}-1^{\prime}\right), 4.48-4.42\left(\mathrm{~m}, 1 \mathrm{H} ; \mathrm{H}-3^{\prime}\right), 4.10(\mathrm{q}, J=3.7 \mathrm{~Hz}, 1 \mathrm{H}$; $\left.\mathrm{H}-4^{\prime}\right), 3.63\left(\mathrm{~s}, 6 \mathrm{H} ; \mathrm{OCH}_{3}\right), 3.50-3.27\left(\mathrm{~m}, 4 \mathrm{H}\right.$; fluorene- $\left.\mathrm{CH}_{2}+\mathrm{H}-5^{\prime}\right)$, 2.56-2.34 (m, 2H; H-2 $)$; ${ }^{13} \mathrm{C}$ NMR (125 $\left.\mathrm{MHz} \mathrm{CDCl}_{3}\right): \delta$ 162.1, 158.5, 149.9, 144.3 143.5, 143.3, 141.4, 141.2, 136.5, 135.3, 135.4, 130.3, 130.0, 129.8, 129.7, 127.8, 127.0, 126.7, 126.6, 124.9, 119.9, 119.6, 116.3, 113.1, 86.6, 86.3, 85.3, 72.3, 63.3, 55.0, 41.4, 36.5; HRMS-FAB $(\mathrm{m} / \mathrm{z})$ : $[\mathrm{M}]^{+}$calcd for $\mathrm{C}_{43} \mathrm{H}_{38} \mathrm{~N}_{2} \mathrm{O}_{7}, 694.2679$; found, 694.2683.

$5^{\prime}$-O-(4,4' -Dimethoxytrityl)-2' -deoxy-5-[(9H-fluoren-2-yl)buta-1,3diyn-1-yl] uridine (8). Using a procedure similar to that described for 7 , this product was obtained in a yield of $79 \%$ : $\mathrm{mp}>180^{\circ} \mathrm{C} \mathrm{dec}$; IR (film): $\nu$ 2929, 2359, 1697, 1607, 1507, 1456, 1277, 1249, 1092, 1033, 825, $733 \mathrm{~cm}^{-1} ;{ }^{1} \mathrm{H}$ NMR (500 MHz, DMSO- $d_{6}$ ): $\delta 11.83(\mathrm{~s}, 1 \mathrm{H}$; $\mathrm{NH}$ ), 8.16 (s, 1H; H-6), 7.97 (dd, $J=7.9,4.5 \mathrm{~Hz}, 2 \mathrm{H}$; fluorene-H), 7.75 (s, 1H; fluorene-H), 7.62 (d, $J=7.3 \mathrm{~Hz}, 1 \mathrm{H}$; fluorene-H), 7.58 (d, $J=7.9 \mathrm{~Hz}, 1 \mathrm{H}$; fluorene-H), 7.43-7.23 (m, 11H; fluorene$\mathrm{H}+\mathrm{DMTr}-\mathrm{H}), 6.90(\mathrm{t}, J=8.8 \mathrm{~Hz}, 4 \mathrm{H} ; \mathrm{DMTr}-\mathrm{H}), 6.11(\mathrm{t}, J=$ $\left.6.5 \mathrm{~Hz}, 1 \mathrm{H} ; \mathrm{H}-1^{\prime}\right), 5.34$ (d, $\left.J=4.5 \mathrm{~Hz}, 1 \mathrm{H} ; \mathrm{H}-3^{\prime}\right), 4.33-4.28(\mathrm{~m}, 1 \mathrm{H}$; $\left.\mathrm{H}-4^{\prime}\right), 3.97$ (s, 2H; fluorene- $\left.\mathrm{CH}_{2}\right), 3.73\left(\mathrm{~s}, 6 \mathrm{H} ; \mathrm{OCH}_{3}\right), 3.29-3.14(\mathrm{~m}$, $2 \mathrm{H} ; \mathrm{H}^{5} 5^{\prime}$ ), 2.35-2.22 (m, 2H; H-2'); ${ }^{13} \mathrm{C}$ NMR (125 MHz, DMSO- $d_{6}$ ): $\delta 161.5,158.1,149.2,145.5,144.7,143.7,143.5,142.7,140.1$, 135.6, 135.3, 131.3, 129.7, 129.6, 128.8, 127.9, 127.7, 127.0, 126.7, 125.3, 
120.8, 120.5, 118.5, 113.2, 97.1, 86.0, 85.9, 85.5, 82.6, 76.9, 75.1, 73.8, 70.2, 63.6, 55.0, 36.3; HRMS-FAB $(\mathrm{m} / \mathrm{z}):[\mathrm{M}]^{+}$calcd for $\mathrm{C}_{47} \mathrm{H}_{38} \mathrm{~N}_{2} \mathrm{O}_{7}, 742.2679$; found, 742.2682.

5'-O-[Bis(4-methoxyphenyl)phenylmethyl]-2'-deoxy-5-(9H-fluoren-2-yl)-3' -[2-cyanoethylbis(1-methylethyl)phosphoramidyl]uridine (9). 2-Cyanoethyl $N, N$-diisopropylchlorophosphoramidite $(77.0 \mu \mathrm{L}, 0.344 \mathrm{mmol})$ was added dropwise to a solution of 7 (200 mg, $0.288 \mathrm{mmol})$ and $N$-methylmorpholine $(95.0 \mu \mathrm{L}, 0.862$ $\mathrm{mmol})$ in $\mathrm{CH}_{2} \mathrm{Cl}_{2}(7.2 \mathrm{~mL})$ and then the mixture was stirred at room temperature for $30 \mathrm{~min}$. Evaporation of the solvent in vacuo and purification of the residue through short column chromatography $\left(\mathrm{SiO}_{2}\right.$; hexane/EtOAc, $\left.1: 1\right)$ yielded 9 (227 $\left.\mathrm{mg}, 88 \%\right): \mathrm{mp}$ $>80{ }^{\circ} \mathrm{C}$ dec; IR (film): $\nu$ 2960, 2923, 2851, 2358, 1685, 1607, 1509, 1459, 1249, 1177, 1031, 977, 878, 827, 756, 736, 701, 641, $603 \mathrm{~cm}^{-1} ;{ }^{1} \mathrm{H}$ NMR $\left(500 \mathrm{MHz}, \mathrm{CDCl}_{3}\right): \delta 7.85$ and $7.80(2 \mathrm{~s}, 1 \mathrm{H}$; $\mathrm{NH}), 7.63$ and 7.61 (2s, $1 \mathrm{H}$; H-6), 7.41-7.31 (m, 4H; fluorene-H), 7.30-7.40 (m, 12H; fluorene-H + DMTr-H), 6.60-6.50 (m, 4H; DMTr-H), 6.39-6.32 (m, 1H; H-1'), 4.58-4.52 (m, 1H; H-3'), 4.19$4.23\left(\mathrm{~m}, 1 \mathrm{H} ; \mathrm{H}-4^{\prime}\right), 3.85-3.74\left(\mathrm{~m}, 1 \mathrm{H} ; \mathrm{OCH}_{2}\right), 3.72(\mathrm{~s}, 2 \mathrm{H}$; fluorene$\mathrm{CH}_{2}$ ), 3.70-3.59 (m, $1 \mathrm{H} ; \mathrm{OCH}_{2}$ ), 3.54 and $3.53\left(2 \mathrm{~s}, 6 \mathrm{H} ; \mathrm{OCH}_{3}\right)$, 3.43-3.12 (m, $\left.4 \mathrm{H} ; \mathrm{NCH}+\mathrm{H}-5^{\prime}\right), 2.62-2.49\left(\mathrm{~m}, 2 \mathrm{H} ; \mathrm{CH}_{2} \mathrm{CN}+\mathrm{H}-2^{\prime}\right)$, 2.39-2.21 (m, 2H; $\left.\mathrm{CH}_{2} \mathrm{CN}+\mathrm{H}-2^{\prime}\right), 1.20-1.18\left(\mathrm{~m}, 12 \mathrm{H}, \mathrm{NCHCH}_{3}\right)$; ${ }^{31} \mathrm{P}$ NMR (202 MHz, $\left.\mathrm{CDCl}_{3}\right): \delta$ 149.1, 148.6.

5'-O-[Bis(4-methoxyphenyl)phenylmethyl]-2'-deoxy-5-[(9H-fluoren-2-yl)buta-1,3-diyn-1-yl]-3' -[2-cyanoethylbis(1-methylethyl)phosphoramidyl]uridine (10). Using a procedure similar to that described for $\mathbf{9}$, this product was obtained in a yield of $76 \%$ : $\mathrm{mp}$ $>72{ }^{\circ} \mathrm{C} \mathrm{dec} ;{ }^{1} \mathrm{H}$ NMR (500 MHz, DMSO- $\left.d_{6}\right): \delta 8.22$ and 8.23 (2s, $1 \mathrm{H} ; \mathrm{NH}), 7.99$ and $7.97(2 \mathrm{~s}, 1 \mathrm{H} ; \mathrm{H}-6), 7.76(\mathrm{~d}, J=3.5 \mathrm{~Hz}, 1 \mathrm{H}$; fluorene-H), 7.62 (d, $J=7.4 \mathrm{~Hz}, 1 \mathrm{H}$; fluorene-H), 7.59-7.56 (m, $2 \mathrm{H}$; fluorene-H), 7.43-7.22 (m, 12H; fluorene-H + DMTr-H), 6.91-6.88 (m, 4H; DMTr-H), 6.11 (m, 1H; H-1'), 4.54-4.48 (m, $\left.1 \mathrm{H} ; \mathrm{H}-3^{\prime}\right), 4.12-4.01\left(\mathrm{~m}, 1 \mathrm{H} ; \mathrm{H}-4^{\prime}\right), 3.97$ (s, $2 \mathrm{H}$; fluorene- $\mathrm{CH}_{2}$ ), $3.90-3.80\left(\mathrm{~m}, 1 \mathrm{H} ; \mathrm{OCH}_{2}\right), 3.75$ and $3.74\left(2 \mathrm{~s}, 6 \mathrm{H} ; \mathrm{OCH}_{3}\right), 3.64-$ 3.54 (m, 3H; $\left.\mathrm{OCH}_{2}+\mathrm{NCH}\right), 3.27-3.19$ (m, 2H; H-5'), 2.80-2.76 $\left(\mathrm{m}, 2 \mathrm{H} ; \mathrm{CH}_{2} \mathrm{CN}+\mathrm{H}-2^{\prime}\right), 2.68-2.64\left(\mathrm{~m}, 2 \mathrm{H} ; \mathrm{CH}_{2} \mathrm{CN}+\mathrm{H}-2^{\prime}\right) 1.14-$ $0.98\left(\mathrm{~m}, 12 \mathrm{H}, \mathrm{NCHCH}_{3}\right) ;{ }^{31} \mathrm{P}$ NMR $\left(202 \mathrm{MHz}, \mathrm{CDCl}_{3}\right): \delta$ 147.7, 147.3.

\section{Synthesis of oligonucleotides}

ODNs were prepared using the $\beta$-cyanoethylphosphoramidite method on controlled pore glass supports $(1 \mu \mathrm{mol})$ with a POLYGEN Professional 12-Column DNA synthesizer and standard methods. ${ }^{20}$ After automated synthesis, the oligonucleotides were cleaved from the solid support and deprotected through treatment with $30 \%$ aqueous $\mathrm{NH}_{4} \mathrm{OH}(1.0 \mathrm{~mL})$ for $10 \mathrm{~h}$ at $55{ }^{\circ} \mathrm{C}$. The crude products from the automated ODN synthesis were lyophilized and diluted with distilled water $(1 \mathrm{~mL})$; they were then purified using high-performance liquid chromatography (HPLC; Grace VyDAC ${ }^{\mathrm{TM}} \mathrm{C} 18$ column, $250 \times 10 \mathrm{~mm}$; pore size: $120 \AA$ ). The HPLC mobile phase was held isocratically for 10 min using 5\% MeCN/0.1 M triethylammonium acetate (TEAA; pH 7.0) at a flow rate of $2.5 \mathrm{~mL} \mathrm{~min}^{-1}$. The gradient was then increased linearly over $10 \mathrm{~min}$ from $5 \% \mathrm{MeCN} / 0.1 \mathrm{M}$ TEAA to $50 \% \mathrm{MeCN} / 0.1 \mathrm{M}$ TEAA at the same flow rate. The fractions containing the purified ODN were pooled and lyophilized.
Aqueous $\mathrm{AcOH}(80 \%)$ was added to the ODN; after standing for $30 \mathrm{~min}$ at ambient temperature, the $\mathrm{AcOH}$ was evaporated under reduced pressure. The residue was diluted with water (1 $\mathrm{mL}$ ) and then the solution was purified through HPLC under the same conditions described above. The concentrations of the ODNs were determined through measurement of UV-Vis absorptions. MALDI-TOF mass spectra of the ODNs were recorded using a Kratos Analytical AXIMA LNR MALDI TOF mass spectrometer operated in the linear mode with an $8: 1$ mixture of 3-hydroxypicolinic acid (0.35 M) and ammonium citrate $(0.1 \mathrm{M})$ as the matrix; the accelerating voltage was $20 \mathrm{kV}$.

\section{Melting temperatures $\left(T_{\mathrm{m}}\right)$}

All values of $T_{\mathrm{m}}$ of the ODNs $(1.5 \mu \mathrm{M})$ were recorded in $10 \mathrm{mM}$ Tris-HCl buffer ( $\mathrm{pH}$ 7.2) containing $100 \mathrm{mM} \mathrm{NaCl}$ and $20 \mathrm{mM}$ $\mathrm{MgCl}_{2}$. Absorbance-temperature profiles were measured at $260 \mathrm{~nm}$ using a Cary 100 Conc UV-Vis spectrophotometer equipped with a temperature controller (cell path length: $1 \mathrm{~cm}$ ). The absorbance of the samples was monitored at $260 \mathrm{~nm}$ upon varying the temperature from 5 to $90{ }^{\circ} \mathrm{C}$ at a heating rate of $1{ }^{\circ} \mathrm{C} \min ^{-1}$. Melting temperatures were determined using a derivative method and Cary Win UV thermal application software. Each measurement was run in triplicate.

\section{UV and fluorescence spectroscopy}

ODN solutions were prepared as described above for the measurement of the melting temperatures. Absorption spectra were recorded using a Cary 100 Conc UV-Vis spectrophotometer (cell path length: $1 \mathrm{~cm}$ ). Fluorescence spectra were recorded using a Cary Eclipse fluorescence spectrophotometer (cell path length: $1 \mathrm{~cm}$; excitation at absorption maximum).

\section{Optimized structure calculations}

To understand absorption and emission phenomena of the nucleosides, the theoretical calculations were carried out by using the software package Gaussian 09 D. ${ }^{21}$ The calculation using B3LYP level with 6-31G basis set provided the optimized geometries at ground states $\left(\mathrm{S}_{0}\right)$ and excited states $\left(\mathrm{S}_{1}\right)$ and the images of the optimized structures were described in ESI. $\dagger$

\section{Conflicts of interest}

There are no conflicts to declare.

\section{Acknowledgements}

This study was supported by the Basic Science Research Program through the National Research Foundation of Korea (NRF) funded by the Ministry of Education (2017R1D1A1B03034920).

\section{Notes and references}

1 (a) M. Sharifi, M. Futema, D. Nair and S. E. Humphries, Curr. Cardiol. Rep., 2019, 21, 43; (b) X. M. Wei, X. C. Ju, X. Yi, Q. Zhu, N. Qu, T. F. Liu, Y. Chen, H. Jiang, G. H. Yang, R. Zhen, Z. Z. Lan, M. Qi, J. M. Wang, Y. Yang, Y. X. Chu, 
X. Y. Li, Y. F. Guang and J. Huang, PLoS One, 2011, 6, e29500; (c) G. H. Luo, L. Zheng, X. Y. Zhang, J. Zhang, P. Nilsson-Ehle and N. Xu, Anal. Biochem., 2009, 386, 161-166.

2 (a) S. Tyagi, D. P. Bratu and F. R. Kramer, Nat. Biotechnol., 1998, 16, 49-53; (b) A. S. Piatek, S. Tyagi, A. C. Pol, A. Telenti, L. P. Miller, F. R. Kramer and D. Alland, Nat. Biotechnol., 1998, 16, 359-363; (c) S. Tyagi and F. R. Kramer, Nat. Biotechnol., 1996, 14, 303-308.

3 G. T. Hwang, Molecules, 2018, 23, 124.

4 (a) J. W. Lee, Y.-S. Son, J. Y. Hwang, Y. Park and G. T. Hwang, Org. Biomol. Chem., 2017, 15, 7165-7172; (b) J. Lee, H. Y. Cho and G. T. Hwang, ChemBioChem, 2013, 14, 1353-1362; (c) J. H. Ryu, J. Y. Heo, E. K. Bang, G. T. Hwang and B. H. Kim, Tetrahedron, 2012, 68, 72-78; (d) Y. A. Lee and G. T. Hwang, Bull. Korean Chem. Soc., 2010, 31, 2011-2014; (e) J. H. Ryu, Y. J. Seo, G. T. Hwang, J. Y. Lee and B. H. Kim, Tetrahedron, 2007, 63, 3538-3547; $(f)$ G. T. Hwang, Y. J. Seo and B. H. Kim, J. Am. Chem. Soc., 2004, 126, 6528-6529.

5 (a) K. Murayama and H. Asanuma, ChemBioChem, 2020, 21, 120-128; (b) K. T. Kim, R. N. Veedu, Y. J. Seo and B. H. Kim, Chem. Commun., 2014, 50, 1561-1563; (c) C. Boonlua, B. Ditmangklo, N. Reenabthue, C. Suparpprom, N. Poomsuk, K. Siriwong and T. Vilaivan, RSC Adv., 2014, 4, 8817-8827; (d) K. K. Karlsen, A. Okholm, J. Kjems and J. Wengel, Bioorg. Med. Chem., 2013, 21, 6186-6190; (e) A. Okamoto, Y. Saito and I. Saito, J. Photochem. Photobiol., C, 2005, 6, 108-122.

6 (a) M. Tanaka, B. Elias and J. K. Barton, J. Org. Chem., 2010, 75, 2423-2428; (b) K. Tainaka, M. Fujitsuka, T. Takada, K. Kawai and T. Majima, J. Phys. Chem. B, 2010, 114, 14657-14663; (c) P. Daublain, A. K. Thazhathveetil, Q. Wang, A. Trifonov, T. Fiebig and F. D. Lewis, J. Am. Chem. Soc., 2009, 131, 16790-16797; (d) S. T. Gaballah, J. D. Vaught, B. E. Eaton and T. L. Netzel, J. Phys. Chem. B, 2005, 109, 5927-5934; (e) N. Amann, E. Pandurski, T. Fiebig and H. A. Wagenknecht, Chem.-Eur. J., 2002, 8, 4877-4883.

7 (a) G. H. Luo, L. Zheng, X. Y. Zhang, J. Zhang, P. Nilsson-Ehle and N. Xu, Anal. Biochem., 2009, 386, 161-166; (b) C. A. M. Seidel, A. Schulz and M. H. M. Sauer, J. Phys. Chem., 1996, 100, 5541-5553.

8 (a) N. P. F. Barthes, I. A. Karpenko, D. Dziuba, M. Spadafora, J. Auffret, A. P. Demchenko, Y. Mely, R. Benhida, B. Y. Michel and A. Burger, RSC Adv., 2015, 5, 33536-33545; (b) A. A. Tanpure and S. G. Srivatsan, ChemBioChem, 2014, 15,
1309-1316; (c) D. G. Lee, I. S. Kim, J. W. Park and Y. J. Seo, Chem. Commun., 2014, 50, 7273-7276; (d) M. Tanaka, K. Oguma, Y. Saito and I. Saito, Bioorg. Med. Chem. Lett., 2012, 22, 4103-4105; (e) S. S. Bag, R. Kundu, K. Matsumoto, Y. Saito and I. Saito, Bioorg. Med. Chem. Lett., 2010, 20, 3227-3230; $(f)$ H. S. Jeong, S. Kang, J. Y. Lee and B. H. Kim, Org. Biomol. Chem., 2009, 7, 921-925; $(g)$ Q. Xiao, R. T. Ranasinghe, A. M. P. Tang and T. Brown, Tetrahedron, 2007, 63, 3483-3490; (h) Y. Saito, Y. Miyauchi, A. Okamoto and I. Saito, Tetrahedron Lett., 2004, 45, 78277831; (i) A. Okamoto, K. Kanatani and I. Saito, J. Am. Chem. Soc., 2004, 126, 4820-4827.

9 A. A. Tanpure and S. G. Srivatsan, ChemBioChem, 2012, 13, 2392-2399.

10 T. Kanamori, H. Ohzeki, Y. Masaki, A. Ohkubo, M. Takahashi, K. Tsuda, T. Ito, M. Shirouzu, K. Kuwasako, Y. Muto, M. Sekine and K. Seio, ChemBioChem, 2015, 16, 167-176.

11 S. S. Bag, M. K. Pradhan, S. K. Das, S. Jana and R. Bag, Bioorg. Med. Chem. Lett., 2014, 24, 4678-4681.

12 (a) M. S. Noe, R. W. Sinkeldam and Y. Tor, J. Org. Chem., 2013, 78, 8123-8128; (b) R. W. Sinkeldam, P. Marcus, D. Uchenik and Y. Tor, ChemPhysChem, 2011, 12, 22602265; (c) R. W. Sinkeldam, N. J. Greco and Y. Tor, ChemBioChem, 2008, 9, 706-709.

13 Q. Xiao, R. T. Ranasinghe, A. M. P. Tang and T. Brown, Tetrahedron, 2007, 63, 3483-3490.

14 K. S. Sindhu, A. P. Thankachan, P. S. Sajitha and G. Anilkumar, Org. Biomol. Chem., 2015, 13, 6891-6905.

15 D. Listunov, N. Saffon-Merceron, E. Joly, I. Fabing, Y. Genisson, V. Maraval and R. Chauvin, Tetrahedron, 2016, 72, 6697-6704.

16 T. F. Tani Hisaya and M. Koreyasu, Bull. Chem. Soc. Jpn., 1963, 36, 391-396.

17 H. Y. Cho, S. K. Woo and G. T. Hwang, Molecules, 2012, 17, 12061-12071.

18 C. A. Parker, Photoluminescence of solutions. With applications to photochemistry and analytical chemistry, Elsevier Pub. Co., Amsterdam, New York etc., 1968.

19 (a) S. Kamoto, M. Hyuga and T. Kato, Analyst, 2016, 141, 6087-6092; (b) A. Okamoto, K. Tainaka, Y. Ochi, K. Kanatani and I. Saito, Mol. BioSyst., 2006, 2, 122-126.

20 M. J. Gait, Oligonucleotide synthesis: a practical approach, IRL Press, Oxford Oxfordshire, Washington, DC, 1984.

21 M. J. Frisch, et al., Gaussian 09, Revision D. 01, Gaussian. Inc., Wallingford, CT, 2009. 